\title{
RESEARCH ON LEACHATE WATER
}

\author{
Karin Hellat \\ University of Tartu \\ Estonia
}

\begin{abstract}
Data on leachate water of Kohtla-Järve semicoke heaps, containing high concentrations of phenolic compounds, are presented and technologies for it treatment are reported. The parameters of biodegradability of runoff water are compared to the other wastewater's of that area.
\end{abstract}

\section{LEACHATE FROM SEMICOKE HEAPS}

Leachate water from Kohtla-Järve semicoke ash heaps is still environmentally incompletely solved problem in North East of Estonia.

Amount of runoff water is about $700000 \mathrm{~m}^{3}$ annually, that means the daily runoff ca $2000 \mathrm{~m} 3$. Runoff flowrates from the ash heaps during periods of storm events and snow melt may achieve a maximum flow of $10000 \mathrm{~m}^{3} / \mathrm{d}$. The strongly polluted with phenols leachate was collected by a drainage ditch and discharged into River Kohtla, further into River Purtse and the Gulf of Finland.

The data about leachate water analyses are reported in the table 1. 
Table 1: Data on RAS Kiviter ash heaps leachate water

\begin{tabular}{|c|c|c|c|c|c|}
\hline \multirow[t]{2}{*}{ PARAMETERS } & \multirow[t]{2}{*}{ unit } & \multicolumn{2}{|c|}{ in 1993} & \multicolumn{2}{|c|}{ in 1995} \\
\hline & & $\min$ & $\max$ & $\min$ & $\max$. \\
\hline flow & $\mathrm{m}^{3} / \mathrm{d}$ & 0 & 10000 & 0 & 8700 \\
\hline $\mathrm{pH}$ & $\mathrm{pH}$ unit & 6.6 & 12.3 & 6,95 & 12,1 \\
\hline COD & $\mathrm{mgO}_{2} / 1$ & 113 & 5500 & 226 & 3272 \\
\hline $\mathrm{BOD}$, & $\mathrm{mgO}_{2} / 1$ & 40 & 2320 & 68 & 1650 \\
\hline $\mathrm{BOD}_{\mathrm{T}}$ & $\mathrm{mgO}_{2} / 1$ & 80 & 2880 & 116 & 1880 \\
\hline volatile phenols & $\mathrm{mg} / \mathrm{l}$ & 1,1 & 130 & 1,9 & 97.0 \\
\hline phenols (sum) & $\mathrm{mg} / \mathrm{l}$ & 1,6 & 236 & 2,5 & 144 \\
\hline SS & $\mathrm{mg} / \mathrm{l}$ & 15 & 400 & 34 & 336 \\
\hline tot $\mathrm{N}$ & $\mathrm{mg} / \mathrm{l}$ & 2,5 & 85,4 & 5,6 & 78,4 \\
\hline tot $\mathrm{P}$ & $\mathrm{mg} / \mathrm{l}$ & 0,13 & 0,8 & 0 & 0.5 \\
\hline chlorides & $\mathrm{mg} / \mathrm{l}$ & 142 & 2842 & 295 & 1862 \\
\hline sulphates & $\mathrm{mg} / \mathrm{l}$ & 119 & 1460 & 217 & 1077 \\
\hline sulphites & $\mathrm{mg} / \mathrm{l}$ & 3,5 & 145 & 46.7 & 592 \\
\hline oil products & $\mathrm{mg} / \mathrm{l}$ & 0,45 & 2.1 & 0.45 & 1.5 \\
\hline
\end{tabular}

From this data it is seen that the quality of the leachate is very variable and not suitable for discharging into the natural water body without treatment when meeting the requirements of HELCOM. This is the reason why the owner of these ash heaps and phenolic ditches, RAS Kiviter, has tried to find a solution to the problem and there was made several proposals to the treatment and stabilisation of leachate water of ash heaps.

In Estonia we have many research centres dealing with the studies of treatment technologies for the leachate water of ash heaps. In November 1996, a special seminar was organised in Lohusalu, Estonia, to discuss the problems concerning wastewater treatment in the region Kohtla-Järve. Several studies were dedicated to the leachate water to find a suitable solution to the treatment process. Some proposals for the treatment process of the leachate water were by using hydrogen peroxide, UV and ozonation purification technologies. It will be possible to oxidise the leachate water by using the photocatalytical methods for the degradation of phenolic compounds in the runoff water. Aerated basins for the pre-treatment of these runoff waters could be also a solution for better quality of leachate. There were made some lab scale and pilot plant measurements in suspended carriers biofilm reactors, trickling filters and lagoons [5]. These experiments showed 
high efficiency in $\mathrm{BOD}, \mathrm{COD}$ and volatile phenolic compounds removal but the summarised phenols in the treated leachate water still remain too high for discharging the leachate into the natural water body.

In some studies, reported in Lohusalu, ecotoxicological analyses of the leachate water of ash heaps were made (Anne Kahru, et al). These results showed some toxicity (EC 50 values up to 50\%) but were rather variable depending on seasons. Oxygen consumption inhibition test by activated sludge (ISO 8192) [2] and "Method for toxicity test with the floating plant, Lemna minor" [3], performed at the University of Tartu, showed also the leachate water quality dependcy from the dilution rate with rainfall and smelting water. In some cases there were found rather high inhibition values both in oxygen consumption rate (EC 50 values above 15\%) and in test with Lemna plants (EC 50 above 35\%). Results were reported at the Central Eastern European Conference on Ecotoxicology and Environmental Safety (SECOTOX) in Jurmala, August, 1997 [4].

When the treatment of the leachate at the site, before the runoff reaches the River Kohtla, is not sufficient, there will stay the problem with the final treatment of the leachate, that must be solved separately. For that purpose could be used the WWTP of RAS Kiviter which is the third biggest waste water treatment plant in Estonia $\left(\sim 35000 \mathrm{~m}^{3} / \mathrm{d}\right)$. Besides of the high waste water load, this treatment plant has very complicated content of the sewage. Additionally to several municipal streams, different industries are sending their wastewater's to the Kohtla-Järve regional WWTP (e.g. from RAS Kiviter all wastewater's except the leachate from ash heaps, from Nitrofert, Velsicol, Püssi, Kiviõli etc.). The WWTP needs complete reconstruction because the hydraulic load is planned to enlarge to 55000 $\mathrm{m}^{3} / \mathrm{d}$. This project is already running in Kohtla-Järve.

\section{BIODEGRADABILITY OF LEACHATE WATER}

Still now the problem concerning to the final treatment of leachate water from the semicoke ash heaps has no really sound solution. If the three lagoons, situated near to the spent shale piles, will have the sufficient treating effect upon the phenolic compounds in the leachate, there will be no need for the use of WWTP as the last step of purification. In the opposite case, for the final purification of the runoff water the Kohtla-Järve regional WWIP will be used. In our study [1] on the biodegradability of all wastewater's of this district we have investigated also the oxygen consumption rate of the leachate water of ash heaps on the activated sludge of Kohtla-Järve WWTP and found it to have good enough parameters of biodegradation, reported in the Table 2. 
Table 2: Comparison of biodegradation parameters of several waste waters in Kohtla-Järve region

\begin{tabular}{||c||c|c|c|c|c|c|}
\hline $\begin{array}{c}\text { Waste water } \\
\text { from: }\end{array}$ & $\begin{array}{c}\mathrm{Q} \\
\mathrm{m}^{3} / \mathrm{d}\end{array}$ & $\begin{array}{c}\mathrm{BOD}_{7} \\
\mathrm{mgO}_{2} / 1\end{array}$ & $\begin{array}{c}\mathrm{BOD}_{2} \\
\mathrm{COD}\end{array}$ & $\begin{array}{c}\mathrm{v}_{\max } \\
\mathrm{mgO}_{2} / \mathrm{min}\end{array}$ & $\begin{array}{c}\mathrm{K} \\
* * *\end{array}$ & $\begin{array}{c}\mathrm{K} \\
* * *\end{array}$ \\
\hline $\begin{array}{c}\text { Kohtla-Nõmme } \\
\text { (municipal) }\end{array}$ & 1080 & 105 & 0,29 & 0,49 & 18,70 & 1,96 \\
\hline $\begin{array}{c}\text { Kohtla-Järve } \\
\text { (municipal) }\end{array}$ & 12300 & 145 & 0,35 & 0,90 & 37,45 & 5,43 \\
\hline Nitrofert (g.c.) & 960 & 162 & 0,53 & 0,24 & 9,73 & 1,58 \\
\hline Velsikol & 380 & 279 & 0,87 & 0,75 & 2,58 & 0,72 \\
\hline $\begin{array}{c}\text { Tar removal } \\
\text { (Ras Kiviter) }\end{array}$ & 7650 & 380 & 0,41 & 0,99 & 7,38 & 2,80 \\
\hline Kiviöli (m. + i.) & 6750 & 820 & 0,44 & 0,73 & 1,33 & 1,09 \\
\hline $\begin{array}{c}\text { Leachate water } \\
\text { from ash heaps }\end{array}$ & $2000 *$ & 940 & 0,50 & 1,20 & 3,31 & 3,11 \\
\hline $\begin{array}{c}\text { Dephenolisation } \\
\text { (RAS Kiviter) }\end{array}$ & 850 & 2160 & 0,49 & 1,33 & 1,25 & 2,70 \\
\hline Püssi (municipal) & $* *$ & 2550 & 0,45 & 0,96 & 2,63 & 6,70 \\
\hline Püssi (industry) & $* *$ & 3920 & 0,45 & 1,06 & 3,44 & 13,48 \\
\hline
\end{tabular}

* not canalised into the Kohtla-Järve WWTP;

** flows not investigated;

*** $\mathrm{v}_{\max }$ - maximum substrate (waste water) consumption rate;

$\mathrm{K}$ - half-biodegadation constant for wastewater;

$\mathrm{K}^{`}$ - particular half-biodegadation constant for wastewater.

Parameters represented in the Table 2 are illustrating the biodegradability of leachate water when comparing it with other inflows to the WWTP. Results show that the leachate could be treated in the treatment plant, investments will be needed for the pipeline building and for the enlargement of the WWTP.

To achieve environmentally sound results of leachate water treatment in KohtlaJärve area, takes maybe even more time than the pollution has lasted at the site. Even all proposed treatment technologies implemented now for the treatment of leachate can't solve the problem immediately because the pollution has reached the natural water bodies and aquifer of that district. One reason, and maybe the most important one, is that the oil shale industry is still functioning with nearly the same technology that $10-20$ years ago, therefore the phenolic fraction in the waste water will remain at the same level. 


\section{REFERENCES}

1. K.Hellat, A.Mashirin, P.Nigu, K.Orupõld, T.Tenno, Biodegradability Studies of Kohtla-Järve Wastewaters by Activated Sludge Respiration, Oil Shale, Vol.14., No 4 Special, pp.509 - 517.

2. ISO 8192 (1986) Water quality - Test for inhibition of oxygen consumption by activated sludge.

3. National Environmental Protection Board (1990) Report 3755: Method for toxicity test with the floating plant, Lemna minor, Duckweed.

4. K.Orupõld, K.Hellat, Ecotoxicology of Some Industrial Effluents from North East of Estonia, SECOTOX 97, Abstracts, 1997, pp.183-184.

5. K.Orupõld, A.Ohlsson, T.Henrysson, Batch Trials to Simulate Biological Treatment in Lagoons of Leachate from Oil-Shale Ash Heaps, Oil Shale, Vol.14., No 4 Special, pp.476-487. 